\title{
Tracing the Mahabharat Thrust (MT) on the basis of lithology and microstructures around Bhainse-Manahari area, central Nepal
}

\author{
*Laxman Subedi ${ }^{1}$ and Kamala Kant Acharya ${ }^{2}$ \\ ${ }^{1}$ Department of Geology, Tri Chandra Campus, Tribhuvan University, Kathmandu, Nepal \\ ${ }^{2}$ Central Department of Geology, Tribhuvan University, Kathmandu, Nepal \\ (*Email: paddock_7@yahoo.com)
}

\begin{abstract}
Lithological and microstructural study carried out in Bhainse-Manahari area, central Nepal reveals that the rock sequences of the Bhainse-Manahari area can be divided into two successions: the Nawakot Complex and the Kathmandu Complex. These two Complexes are separated by a distinct thrust boundary, the Mahabharat Thrust (MT). The Nawakot Complex consists of low-grade metamorphic rocks like slate, phyllite, quartzite and limestone while the Kathmandu Complex comprises medium grade (up to garnet grade) metamorphic rocks like garnet-schist, marble and mica-schist. The Mahabharat Thrust (MT) and the Manahari Thrust (MnT) are the two major thrusts in the study area. The MT separates the rocks of the Nawakot Complex (foot wall) in the south from the rocks of the Kathmandu Complex (hanging wall) in the north. The Manahari Thrust in the western part of the study area separates the Dunga Quartzite and the older Benighat Slates lying above it. The microstructure analysis reveals that the rocks in the thrust zone show higher deformation than in the neighboring rocks, and this gradually decreases away from the MT zone. The strain analysis of quartz grains reveals that the rock sequences of the hanging wall of the MT showed pure, simple and complex shear senses and the rocks of the footwall also showed the same pattern indicating MT as a stretching fault.
\end{abstract}

Keywords: Geology, microstructure, Mahabharat Thrust, Manahari Thrust, strain analysis, Nepal Himalaya

Received: 13 August 2015

Revision accepted: 25 December 2015

\section{INTRODUCTION}

The concept of the Kathmandu Nappe was introduced by Hagen in 1969. Later, Stöcklin and Bhattarai (1977) prepared the aerial photo based geological map of the central Nepal. According to them, this area comprises two units namely the Nawakot Complex and the Kathmandu Complex. The autochthonous sequence represents their Nawakot Complex which is further divided into the Lower and the Upper Nawakot Group. The allochthonous sequence consisting of crystalline rock is thrusting over the Nawakot Group as the large and mappable thrust known as the Mahabharat Thrust (MT). The thrusted mass is contained within the stratigraphic unit of the Kathmandu Complex (Table 1).

After recognition of the Main Central Thrust (MCT) in the Himalaya by Heim and Gansser (1939), a lot of scientific studies were focused on this very important tectonic boundary Hagen (1969), Nadgir et al. (1968-73), Sharma (1973, 1977), Stöcklin and Bhattarai (1977), Morrison and Oliver (1993), Rai et al. (1997), Upreti and Le Fort (1999), Dhital et al. (2000), Jonson et al. (2001), Rai (2001), Robinson et al. (2003), Pearson and DeCelles (2005). The recognition of the MCT as not only a tectonic boundary between the Lesser Himalayan meta-sedimentary rocks and the Higher Himalayan Crystalline rocks, but it also opened the mystery of the famous inverted metamorphism in the Himalayan and the emplacement of the
Tertiary leucogranites in the Himalayas (Stöcklin and Bhattarai (1977), Stöcklin (1980) Upreti and Le Fort (1999). In central Nepal, Stöcklin and Bhattarai (1977) and Stöcklin (1980) mentioned that, the MT is the southward extension of the MCT. However some researchers like Rai et al. (1998); Upreti and Le Fort (1999) claimed that the degree of metamorphism as established by geo-thermometry and the movement history in the MCT and the MT zone are highly contrasting. So they considered it as an out-of-sequence-thrust. Further studies gave rise to the complex deformation and movement history along the MCT. Acharya (2008) carried out deformation analysis along the different parts of the MT. He concluded that the grade of metamorphism is different along the MT and the MCT, but nature of deformation is identical thus he concluded that the Mahabharat Thrust (MT) is the southward extension of the Main Central Thrust (MCT).

The present study was carried out in the southern part of the Kathmandu Nappe around Manahari-Bhainse area, Makwanpur district where autochthonous and allochthonous sequences are separated by the MT (Fig. 1). This work was aimed to study microscopic to macroscopic deformational features and its relation to the thrust zone of the Mahabharat Thrust. This was carried out by image analysis of quartz grains for the qualitative determination of the strain components in the MT Zone. The geological map prepared by Stöcklin (1980) shows numerous vertical faults in the study area (Fig. 2). 
Table 1: Stratigraphic subdivisions of the Kathmandu and Nawakot Complex (Stöcklin and Bhattarai 1977; Stöcklin 1980).

\begin{tabular}{|c|c|c|c|c|c|}
\hline Complex & Group & Formation & Main Lithology & Thickness (m) & Geological Age \\
\hline \multirow{11}{*}{ 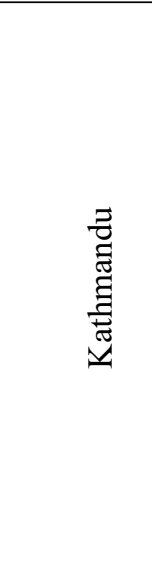 } & \multirow{5}{*}{ Phulchauki } & Godavari Limestone & Limestone & $300-400$ & Devonian \\
\hline & & Chitlang Formation & Slate, Quartzite & 1000 & Silurian \\
\hline & & Chandragiri Limestone & Limestone & 2000 & Cambrian \\
\hline & & Sopyang Formation & Slate, Calc. Phyllite & 200 & Early Cambrian \\
\hline & & Tistung Formation & Metasandstone, Phyllite & 300 & Precambrian \\
\hline & \multirow{6}{*}{ Bhimphedi } & Markhu Formation & Marble, Schist & 1000 & Precambrian \\
\hline & & Kulikhani Formation & Quartzite, Schist & 2000 & Precambrian \\
\hline & & Chisapani Quartzite & Quartzite & 400 & Precambrian \\
\hline & & Kalitar Formation & Schist, Quartzite & 2000 & Precambrian \\
\hline & & Bhainsedobhan Marble & Marble & 800 & Precambrian \\
\hline & & Raduwa Formation & Garnet-Schist & 1000 & Precambrian \\
\hline \multicolumn{6}{|c|}{ Mahabharat Thrust (southward extension of the MCT) } \\
\hline \multirow{8}{*}{ 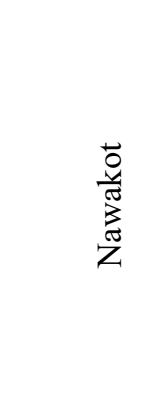 } & \multirow{3}{*}{ 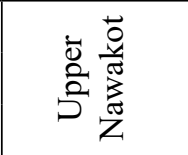 } & Robang Formation & Phyllite, Quartzite & $200-1000$ & Early Paleozoic \\
\hline & & Malekhu Limestone & Limestone, Dolomite & 800 & Precambrian \\
\hline & & Benighat Slates & Slate, Argillites & 3000 & Precambrian \\
\hline & \multirow{5}{*}{ 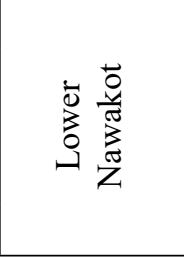 } & Dhading Dolomite & Stromatolitic Dolomite & $500-1000$ & Precambrian \\
\hline & & Nourpul Formation & Phyllite, Metasandstone & 800 & Precambrian \\
\hline & & Dandagaon Phyllite & Phyllite & 1000 & Precambrian \\
\hline & & Fagfog Quartzite & White Quartzite & 400 & Precambrian \\
\hline & & Kuncha Formation & Phyllite, Quartzite & 3000 & Precambrian \\
\hline
\end{tabular}

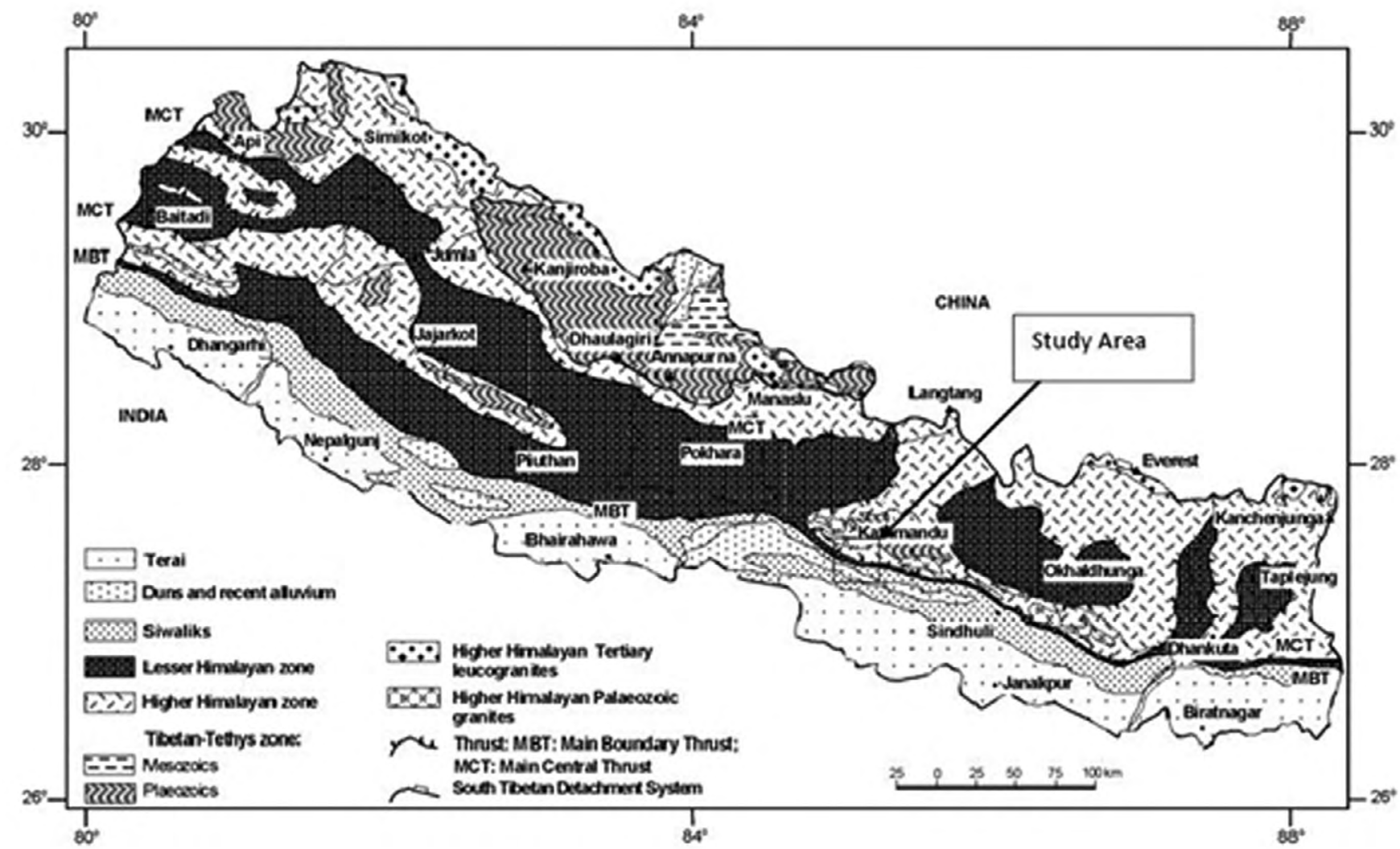

Fig. 1: Simplified geological map of the Himalaya showing major litho-tectonic divisions and the study area (modified after Amatya and Jnawali 1994). 


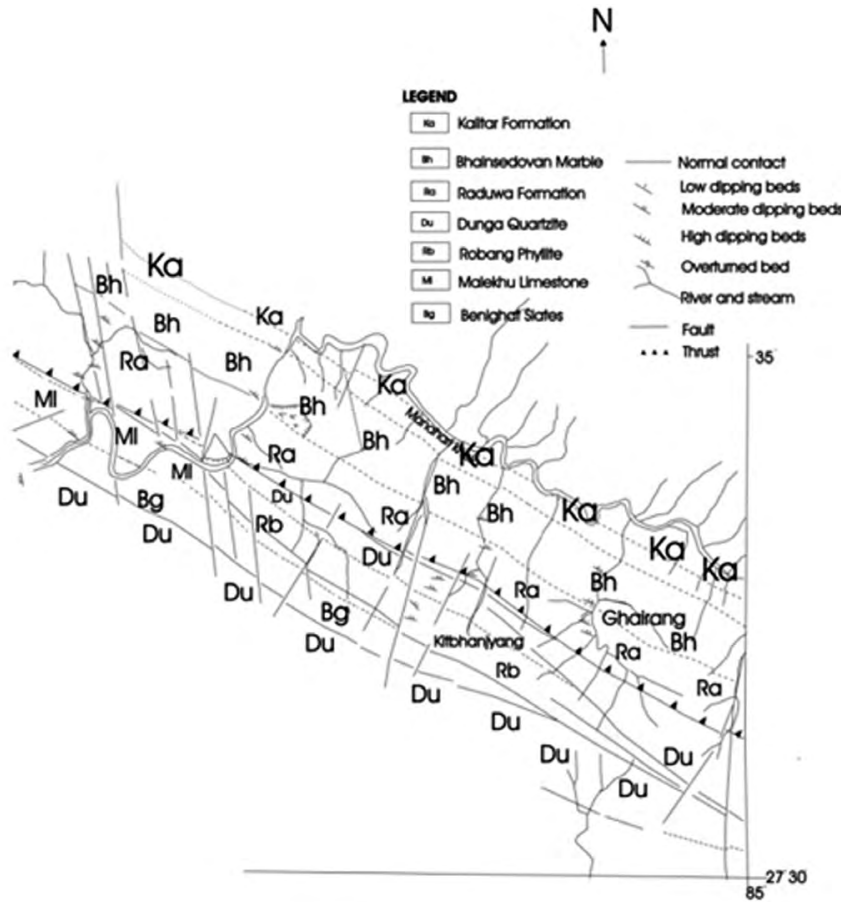

Fig. 2: Geological map of the study area, modified after Stöcklin (1980), unpublished, HMG/UNDP mineral exploration project report.

\section{METHODOLOGY}

Field data were collected to prepare the geological map of the study area in topographical maps at 1:25,000 scale published by the Survey Department, Government of Nepal (1994). Several traverses were made along the different foottrails across the MT section and roads along Manahari and Rapti River sections. A number of oriented rock samples were collected for petrographic study and strain analysis. Thin sections were prepared to know the texture, structure and mineral paragenesis in coarse-grained rocks under the petrographic microscope. Strain analysis was performed using freely available computer software Image J. Photomicrographs of thin section of numerous samples on the hanging wall and foot wall of the MT were studied. For each sample, ellipse major axis, ellipse minor axis and ellipse angle of 25-35 quartz grains were measured. The obtained values were used to calculate the Ellipticity $(\mathrm{R})$ using the formula:

$$
\text { Ellipticity }=\frac{1+\mathrm{e}_{1}}{1+\mathrm{e}_{2}}
$$

Where, $1+\mathrm{e}_{1}$ is the major axis and $1+\mathrm{e}_{2}$ is the minor axis of the grain. The calculated ellipticity was plotted against the ellipse angle that gives certain pattern for pure shear senses and simple shear senses. Most of the laboratory works were carried out in the laboratory at the Central Department of Geology, Tribhuvan University, Kirtipur. Kathmandu, Nepal.

\section{RESULTS}

\section{Lithostratigraphy}

Lithostratigraphically, the area is divided into two complexes namely the Kathmandu Complex and the Nawakot Complex. These complexes are further subdivided into different groups and formations. In this study, all the stratigraphic nomenclature were followed from Stöcklin and Bhattarai (1977). The lithostratigrapy of the area is discussed under two major groups.

\section{Nawakot Complex}

The Nawakot Complex consists almost exclusively of lowgrade metasediments. It has been subdivided into the Lower and the Upper Nawakot Group (Stöcklin and Bhattarai 1977; Stöcklin 1980). In this study, only the rocks of the Upper Nawakot Group (the Benighat Slates, the Malekhu Limestone and the Robang Formation) are exposed in the southern part of the area.

Benighat Slates: The Benighat Slates are well exposed around the Manahari Khola section (Fig. 3). This formation is pinched out in the eastern part of the section. It consists of dark grey to charcoal black, finely laminated slate. The slates are weathered and highly fractured. In weathered condition, it shows ash grey to brown color. The general attitude of the formation is $100^{\circ} / 55^{\circ}$ NE. The Benighat Slates overlies the Dunga Quartzite which is stratigraphically younger (Table 1) in western part of the study area (Fig. 3), indicating the presence of a thrust.

Malekhu Limestone: The Malekhu Limestone consists of platy, thin-bedded dolomitic and siliceous limestone of light-yellow colour, very fine-grained, hard, with thin green sericiticchloritic phyllite partings and intercalations. The Malekhu Limestone overlies the Benighat Slates in the western part (on the Manahari Khola section) whereas it is not observed in the eastern part (Rapti river section). It is well exposed along the Gorandi Khola section and the Manahari Khola section (Fig. 4a). Most of the area covered by this formation is steep and rugged topography. The main lithology of this formation consists of light-grey, to milky-white colored limestone and light-grey to dark-grey dolomite. The formation is pinching towards the eastern side. The southern part of the Formation near the Kothalitar consist milky white to white colored limestone with the alteration of white grey dolomite. The proportion of dark grey colored dolomite gradually increases as moved towards the northern part. The uppermost parts of the Formation consist of the alternating bands of black and grey colored laminated dolomite. The beds are extended along NWSE strike with the steep dipping towards NE $\left(50^{\circ}-70^{\circ}\right)$. The contact between the adjacent formations is transitional.

Robang Phyllite: It consists of sericitic-chlorite phyllites of green grey color (Stöcklin and Bhattarai 1977). This unit is well exposed around the Kothalitar, Kitbhanjyang, and the Rapti river section (Fig. 3). The Robang Phyllite succession in the eastern part along the Manahari Khola is lying between the Malekhu Limestone and the Dunga Quartzite near the 


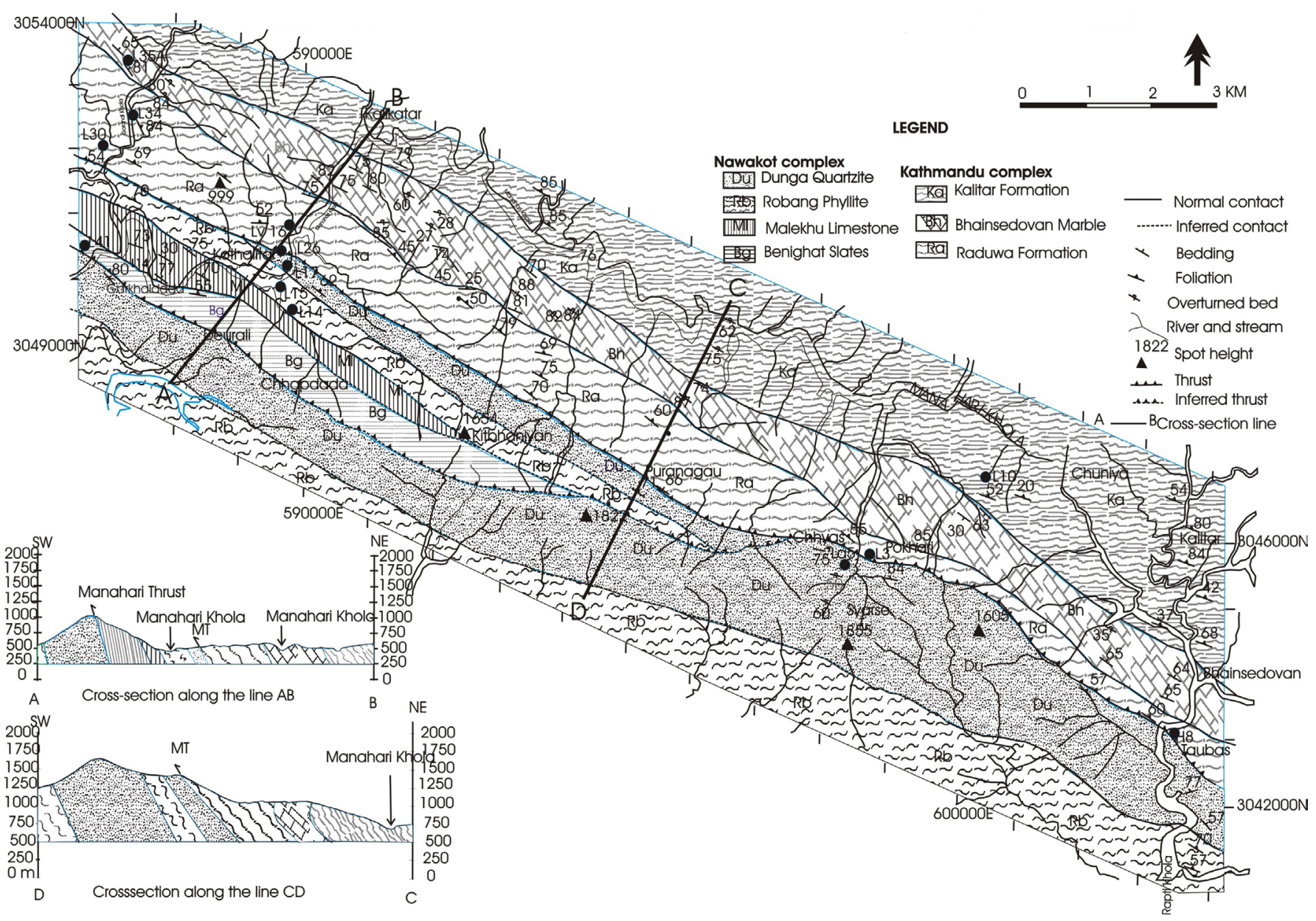

Fig. 3: Geological map of Manahari-Taubas area, central Nepal with cross-section.

Kothalitar village and in the Hetauda-Bhainse road section. This unit shows transitional contact with the Malekhu Limestone (Fig. 4b). The main lithology is phyllite associated with quartzite. The attitude of the formation is $120^{\circ} / 70^{\circ} \mathrm{NE}$. Thin beds of highly deformed Robang Phyllite can be observed below the MT throughout the study area but could not be traced in the map of present scale.

Dunga Quartzite: This unit is well exposed along the Manahari Khola section and Hetauda-Bhainse road section. This unit has a marker lithology and steep slope in the territory. It consists of white, coarsely crystalline, thick to very thick bedded quartzite. In weathered outcrops, it seems brown-yellow or pale-orange colour. Due to the presence of MT above it, the exposures of quartzite in all the parts of the study near the thrust area are deformed. Thin layers of grey phyllite are sometimes intercalated with the competent beds of quartzite. The general attitude of the formation is $119^{\circ} / 57^{\circ} \mathrm{NE}$. Some hematite and malachite mineralizations layers are also observed in this formation.

\section{Kathmandu Complex}

The name is derived from the Kathmandu Valley and is first used by Hagen (1969). The Upper Nawakot Group separates the Kathmandu Complex by the Mahabharat Thrust (MT). The Kathmandu Complex has been divided into the Precambrian
Bhimphedi Group consisting of relatively high-grade metasediments, and the Phulchoki Group of unmetamorphic or weakly metamorphosed sediments containing fossils of early middle Paleozoic age. The two are possibly separated by a slight unconformity. Only the rocks of the Bhimphedi Group: the Raduwa Formation, the Bhainsedobhan Marble and the Kalitar Formation are exposed in the present study area.

Raduwa Formation: This formation is separated from the rock units of the Nawakot Complex by the MT (Fig. 3). The lithology of this formation is garnetiferous schist. Lithologically, the rock is greenish grey pelitic to psammatic schist with garnets, quartz veins, boudins and sometimes actinolite (Fig. 4c). The garnet observed on the western part of the study area are larger in sizes (few $\mathrm{mm}$ to $\mathrm{cm}$ in diameters) whereas in the eastern part are smaller size ranging from microscopic to few $\mathrm{mm}$ in diameters. The garnet mineral present is stretched, elongated and slightly rotated. Hornfels are abundantly observed around the quartz veins. Boudins present in the schist reveals the extensional shearing condition. This formation has sharp contact with the Bhainsedobhan Marble (Fig. 4d). The general attitude of the formation is $124^{\circ} / 72^{\circ} \mathrm{NE}$.

Bhainsedobhan Marble: In the present study, the Bhainsedobhan Marble is well exposed around the Gorandi Khola section, Manahari Khola section above Kothalitar village, HetaudaBhainse road section and in traverse along different foot trails 
(Fig. 3). It is also exposed in the Rapti Khola and the Kitini Khola section around Bhainse. The general attitude of the formation is $114^{\circ} / 82^{\circ} \mathrm{NE}$. In the stratigraphic up section of this formation few overturned beds are observed.

Kalitar Formation: This formation consists of predominantly mica schist with an occasional band of micaceous quartzite. In the present study area, the Kalitar Formation overlies the Bhainsedobhan Marble throughout the northern part. The dominant lithology of this formation is quartzite and schist. Light grey, fine-grained quartzite is intercalated with black coloured, finely-foliated, biotite-containing psammatic schist. The general attitude of the formation is $281^{\circ} / 69^{\circ} \mathrm{NE}$.

\section{Metamorphism}

The rock succession in the hanging wall i.e. in the Kathmandu Complex rock shows higher grade of metamorphism as indicated by garnets in the Raduwa Formation that decreases to the biotite grade in the Kalitar Formation northwards (Fig. 5). The rocks in the foot wall i.e. rocks of the Nawakot Complex shows up to biotite grade near to the MT while the grade decreases to chlorite towards southwards. Thus the rock of foot wall shows the inverted sequences of metamorphism whereas hanging wall shows normal sequence. The rocks in the thrust zone show higher grade of metamorphism and deformation than in the neighboring rocks, and this gradually decreases away from the MT zone.

\section{Geological structures}

The Manahari-Taubas area consists of several regional and local geological structures. The major geological structures in the study area are the MT and the Manahari Thrust. In addition to these structures, the study area consists of numerous mesoscopic folds.
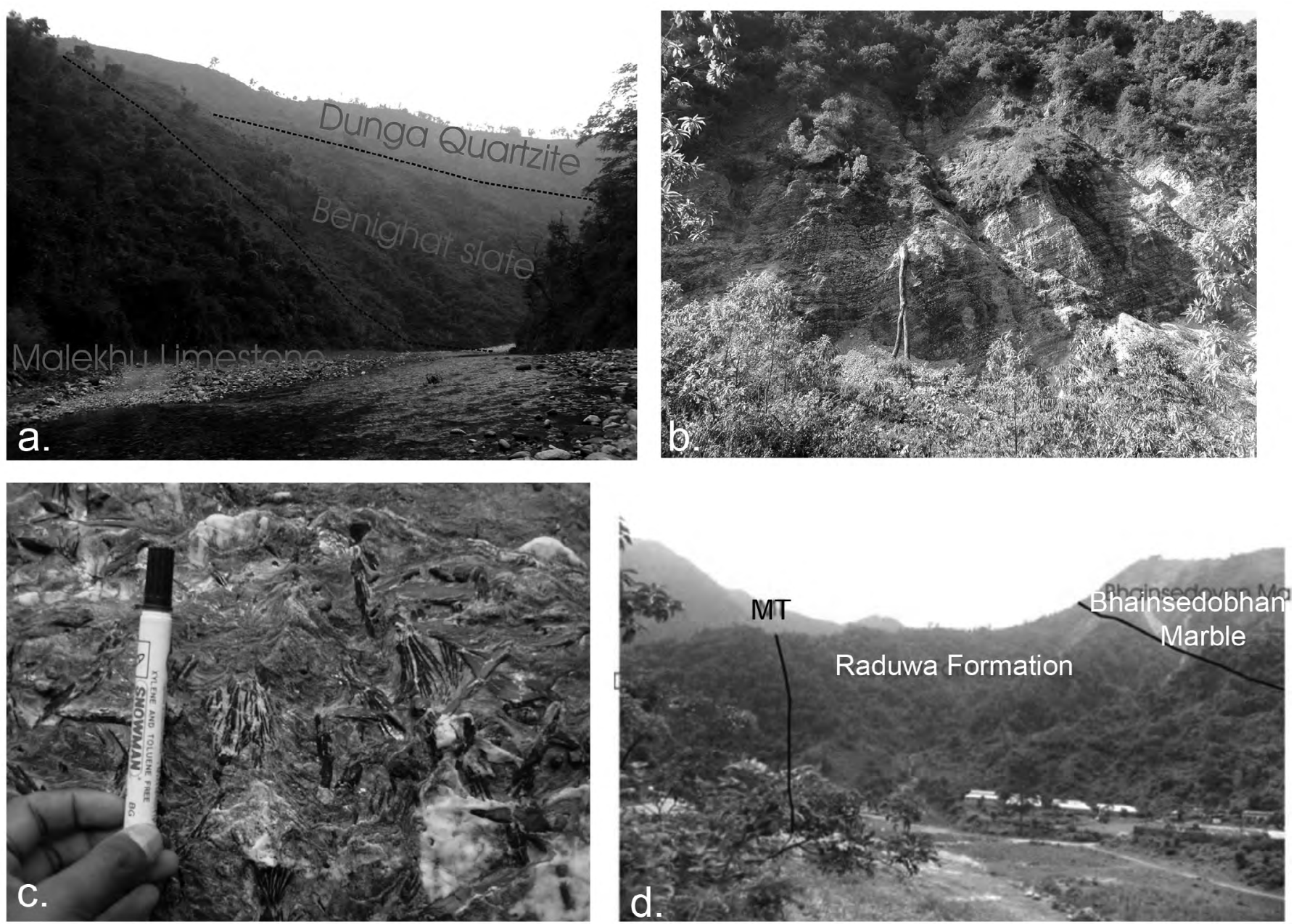

Fig. 4: a. Photograph showing the contact between the Malekhu Limestone, the Benighat Slates and the Dunga Quartzite on the Manahari Khola section, location L20 (Photo facing south), b. Photograph showing the transitional contact between the Malekhu Limestone and the Robang Formation, location L14 (Photo facing SW), c. Photograph showing the actinolite and garnet in schist of the Raduwa Formation exposed on the Gorandi Khola section, location L34 (Photo facing east), d. Photograph showing the contact between the Dunga Quartzite, the Raduwa Formation and the Bhainsedobhan Marble, location $\mathrm{H8}$ (Photo facing west). 

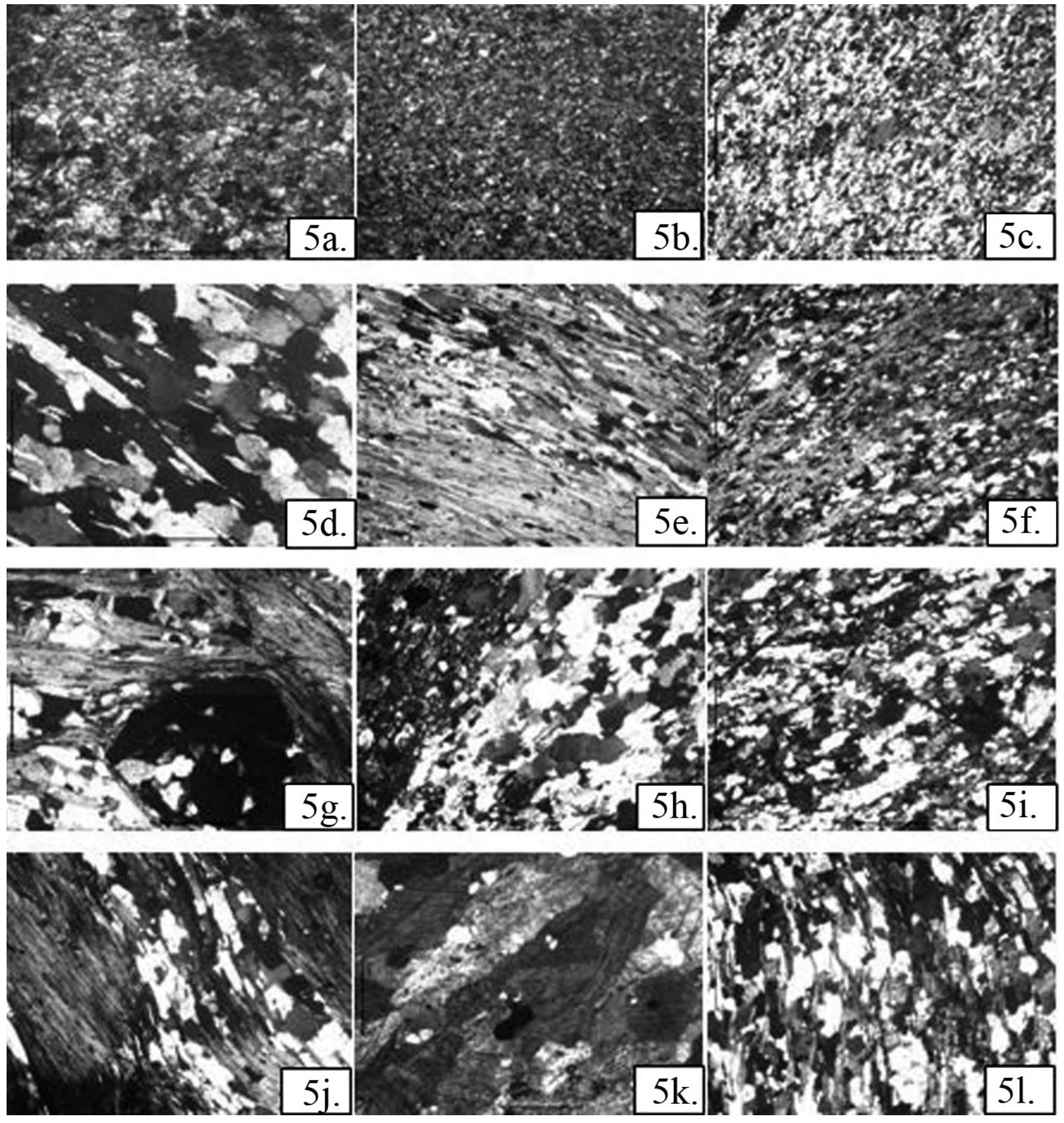

Fig. 5: a. Photomicrograph (4x10, UCN) of dolomitic limestone of the Malekhu Limestone (L14), b. Photomicrograph (4x10, UCN) of dolomite of the Malekhu Limestone (L41), c. Photomicrograph (4x10, UCN) of quartzite of the Raduwa Formation showing recrystallization of quartz and feldspar grains (L15), d. Photomicrograph (4x10, UCN) of quartzite of the Dunga Quartzite showing 1 set of foliation defined by the platy minerals and grain boundary migration recrystallization (La5), e. Photomicrograph $(4 \times 10, \mathrm{UCN})$ of sample prepared from the schist of the Raduwa Formation showing 1 set of foliation and recrystallization of quartz minerals (L17), f. Photomicrograph (4x10, UCN) of sample prepared from schist of the Raduwa Formation showing 1 set of foliation and elongated quartz grains (L3), g. Photomicrograph (4x10, UCN) of sample prepared from schist of the Raduwa Formation showing the garnet (L26), h. Photomicrograph (4x10, UCN) of sample prepared from schist of the Raduwa Formation showing mineral hornblende (Lv16), i. Photomicrograph (4x10, UCN) of sample prepared from schist of the Raduwa Formation (L30), j. Photomicrograph (4x10, UCN) of sample prepared from schist of the Raduwa Formation showing elongated micas and quartz grains (L34), k. Photomicrograph (4x10, UCN) of sample prepared from the Bhainsedobhan Marble showing well developed calcite crystals (L35), I. Photomicrograph (4x10, UCN) of sample prepared from schist of the Kalitar Formation (L10). 
Fig. 6: Minor structures observed in different parts of the ManahariTaubas area: 6a. Boudin observed in the Raduwa Formation along the Manahari Khola (View towards NWW), 6b. Swell-and-pinch structure observed in the Raduwa Formation along the Manahari Khola section (View towards NWW).

Mesoscopic folds: 6c. Z-fold observed in quartzite of the Dunga Quartzite at the Kothalitar showing the top-to-the south-west movement. 6d. S-type fold observed in the Dunga Quartizite, (View towards SE).
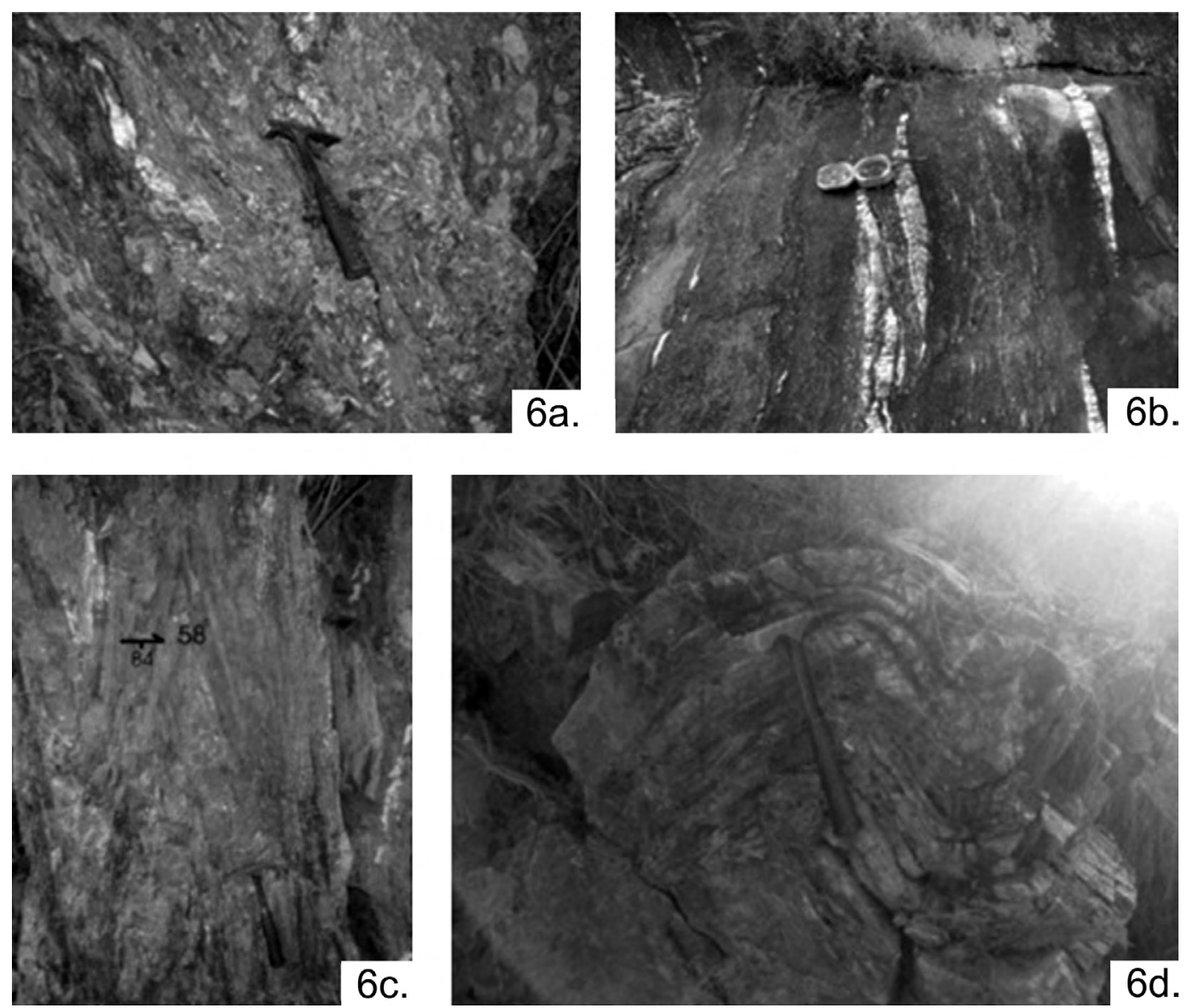

\section{Minor Structures}

Several small-scale structures such as bedding or foliation, lineation, boudins(Fig. 6a), swell and pinch structure (6b) S-type and Z-type folds and superimposed folds are observed in different parts of the study area.

\section{Mesoscopic folds}

A number of mesoscopic folds are observed in the Lesser Himalayan Sequence of the study area ranging from small scale to large scale. Due to the action of the MT, numerous Z-type folds (Fig. 6c) and S-type fold (Fig. 6d) are found in quartzite of the Dunga Quartzite and in the Raduwa Formation.

\section{Micro Structures}

Near the MT, quartz grains show high deformation (Figs. 7a)and 7c). The same rock type of the Raduwa Formation lying adjacent to the MT show high deformation (Fig. 7d). Similarly the thin section of the Raduwa formation (Fig. 7b) shows the top to the south sense of shear by rolled garnet.

\section{Deformation analysis using software imageJ}

Photomicrograph images of 6 thin sections prepared from the samples collected from different parts of the study area from the vicinity of the MT were analysed using ImageJ (Fig. 8 ). The ellipse major axis, ellipse minor axis and ellipse angle of 25-35 quartz grains have been measured. The Ellipticity was then calculated from the values obtained and have been plotted against the ellipse angle. 
The summery of measured values and calculated ellipticity are given in Table 2. The calculated ellipticities in all the samples are more or less similar except for the sample La5, which shows less ellipticity in compare to the other five samples. The quartz grains of sample L15 shows high average ellipticity.The samples from different locations of the study area on analyzing gave the different pattern of deformation. Samples L30, L15, Lv16 showed simple shear, sample L17 showed pure sear sense while sample La5 and L10 showed complex pattern (Fig. 9). The rocks of the Hanging wall of the MT showed pure, simple and complex sear senses and the rocks of the footwall also showed simple, pure and complex pattern. Thus the MT not only showed simple shear but also there is a prominent pure shear component.
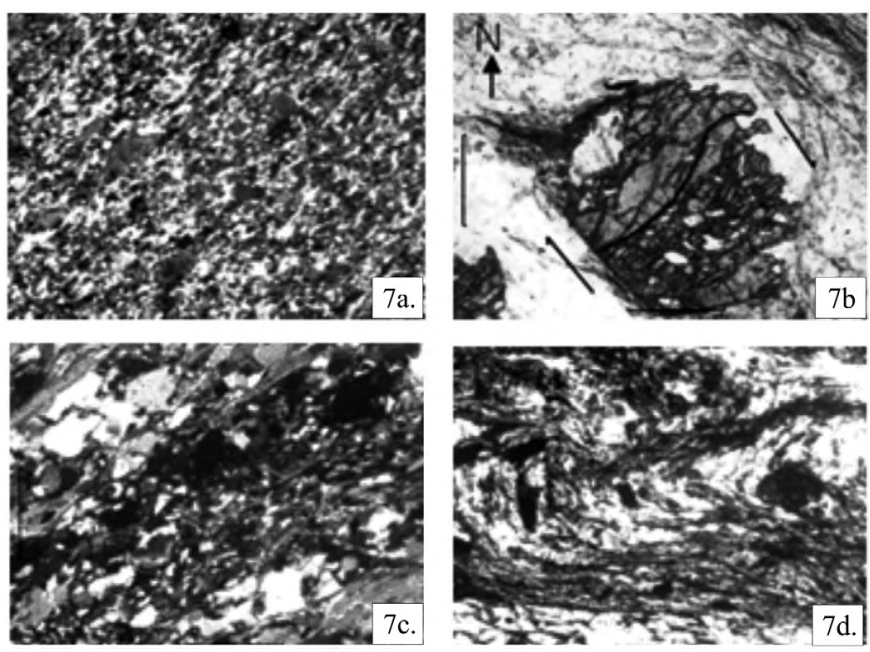

Fig. 7: a. Photomicrograph (UCN, 4X10) showing dynamically recrystallized quartz grains indicating the deformation near the MT. Sample L15 of the Dunga Quartzite, b. Photomicrograph (PPL, 4X10) showing top-to-south shear sense defined by the internal foliation of the garnet. Sample L26 of the Raduwa Formation, c. Photomicrograph (UCN, 4X10) showing dynamically recrystallized quartz grains indicating the deformation near MT. Sample L17of the Robang Phyllite, d. Photomicrograph (PPL, 4X10) showing high deformation and micro scale folding defined by the lineation of platy minerals. Sample $\mathbf{H 8}$ of schist of the Raduwa Formation.

\section{DISCUSSION}

The geological map prepared by Stöcklin (1980) shows numerous vertical faults in the study area (Fig. 2), but the evidences of such faults could not be traced in the present study.

The successions of the Benighat Slates are mapped above the Dunga Quartzite in the western part of present study area in the Manahari Khola section which are separated by a thrust contact named as the Manahari Thrust based on the geological and petrological studies. In some places about 15 $\mathrm{m}$ thick thrust zone is also found in between the slates and quartzite. A number of deformational structures like quartz veins, boudinages, z-type folds, shearing outcrops, intensely folded outcrops are commonly found in the thrust zone and its adjacent areas.

From the petrographic analysis, the rock succession in the hanging wall shows higher grade of metamorphism upwards as indicated by the garnets in the Raduwa Formation that decreases to the biotite grade in the Kalitar Formation northwards. The rocks in the foot wall shows up to biotite grade and to chlorite grade southward from the MT. Thus the rock of foot wall shows the inverted sequences of metamorphism. Rocks in the thrust zone show higher deformation than in the neighboring rocks, and this gradually decreases away from the MT zone. Thus MT can be traced with the help of deformation based criteria (Acharya et al. 2007).

The rotation pattern of syn-tectonic garnet in the MT is similar to that of the rotation of garnet in MCT (Paudel, 2000) and MT zones (Yamaguchi et al. 2004) which indicates the similar nature and environment of the genesis of the Main Central Thrust and the Mahabharat Thrust.

From the image J analysis, samples L30, L15, Lv16 showed simple shear, sample L17showed pure shear sense while samples La5 and L10 showed complex pattern. The rocks of the hanging wall of the MT showed pure, simple and complex shear senses and the rocks of the footwall also showed simple, pure and complex pattern. Thus the MT not only showed simple shear but also there is a prominent pure shear component. Therefore it can be concluded that the rocks had experienced pure shear component earlier in both the walls and simple shear component later. The MT can therefore be characterized as Stretching Fault Thrusting (Means 1989).

Table 2: Summarised data measured and calculated for quartz grains using ImageJ, around the MT.

\begin{tabular}{|l|l|l|l|l|l|l|l|l|}
\hline Sample No. & No. of grains & \multicolumn{2}{|l|}{ Ellipse major axis } & \multicolumn{2}{|l|}{ Ellipse minor axis } & \multicolumn{3}{|c|}{ Ellipticity } \\
\hline & & Max. & Min. & Max. & Min. & Max. & Min. & Mean \\
\hline L30 & 30 & 121.13 & 36.24 & 65.78 & 20.22 & 3.80 & 1.13 & 2.144 \\
\hline L15 & 26 & 106.50 & 22.55 & 59.929 & 10.55 & 4.52 & 1.22 & 2.304 \\
\hline L17 & 25 & 134.19 & 24.308 & 95.95 & 12.68 & 3.85 & 1.12 & 2.23 \\
\hline Lv16 & 25 & 162.43 & 39.76 & 108.08 & 18.029 & 3.71 & 1.29 & 2.18 \\
\hline La5 & 27 & 371.31 & 51.76 & 213.63 & 22.64 & 4.076 & 1.20 & 2.067 \\
\hline L10 & 34 & 193.70 & 32.80 & 77.44 & 27.79 & 6.12 & 1.01 & 2.134 \\
\hline
\end{tabular}



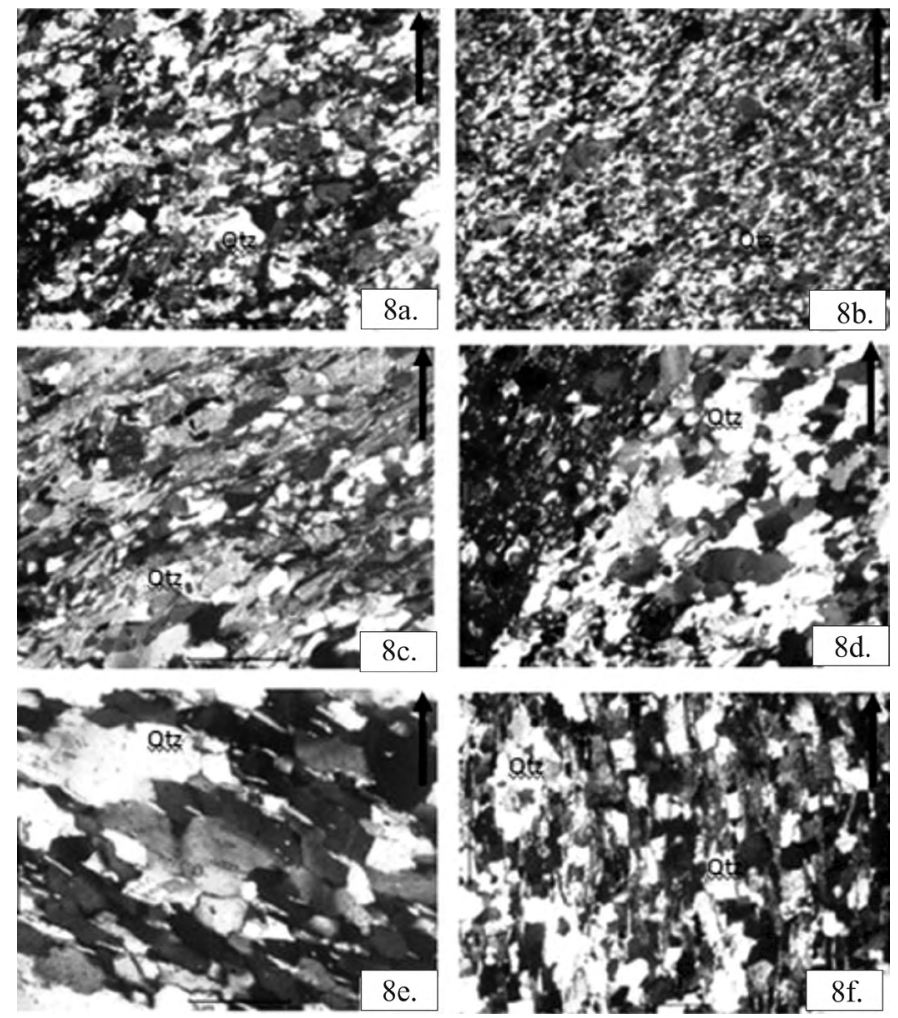

Fig. 8: Representative photomicrograph of rock sample used for ImageJ Analysis (UCN, a, b, c, d, e, f; 4X10) a. sample L30, b. sample L15, c. sample L17, d. sample Lv16, e. sample La5, f. sample L10. Note that samples L30, Lv16, L10 are of hanging wall of the MT and samples L15, L17 and La5 are the samples of foot wall, arrow shows the north direction.
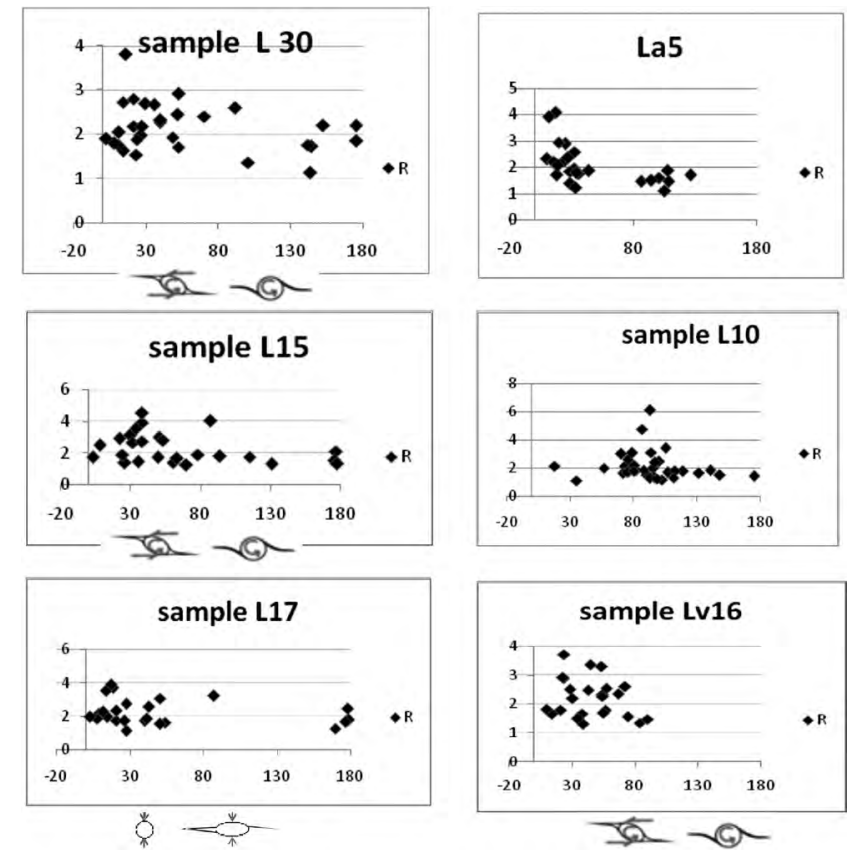

Fig. 9: Ellipticity Vs angle plot of quartz grains around the MT. Sample L30, L10, and Lv16 are taken from the hanging wall whereas samples L15, L17 and La5 are taken from the foot wall of the MT.
The above discussion has been derived from the result obtained by the imageJ analysis of quartz grains, which is a two dimensional tool of strain analysis. However, three dimensional tools for the strain analysis could be used. Therefore, further research in the present study area using the others techniques and adjoining area is recommended.

\section{CONCLUSIONS}

From the present study, following conclusions can be drawn: The rocks of the Manahari-Taubas area can be divided into two successions, the Nawakot Complex and the Kathmandu Complex. The Benighat Slates, the Malekhu Limestone, the Robang Formation and the Dunga Quartzite of the Nawakot Complex and the Raduwa Formation, the Bhainsedobhan Marble and the Kalitar Formation of the Bhimphedi Group of the Kathmandu Complex is observed in the study area separated by a distinct thrust boundary, the MT. The Mahabaharat Thrust (MT) and the Manahari Thrusts (MnT) are the major thrusts in the study area.

From the petrographic analysis, the rock succession in the hanging wall shows higher grade of metamorphism upwards as indicated by the garnets in the Raduwa Formation that decreases to the biotite grade in the Kalitar Formation northwards showing normal sequences. The rocks in the foot wall shows up to biotite grade near the MT and decreases to chlorite grade southward from the MT showing inverted metamorphism. From the micro-structural analysis, rocks in the thrust zone show higher deformation than in the neighboring rocks, and this gradually decreases away from the MT zone. Thus the MT can be traced with the help of deformation based criteria.

From the image $\mathrm{J}$ analysis, the rocks of both hanging wall and foot wall of the MT showed pure, simple and complex shear senses. From this it can be concluded that the MT not only reveals simple shear but also there is a prominent pure shear component. Thus MT can be characterized as stretching thrust system.

\section{ACKNOWLEDGEMENT}

Authors are thankful to Central Department of Geology, Kirtipur, Nepal for providing laboratory facilities.

\section{REFERENCES}

Acharya, K. K., 2008, Qualitative Kinematic Investigations related to the Extrusion of the Higher Himalayan Crystalline and Equivalent Tectonometamorphic Wedges in the Central Nepal Himalaya. $\mathrm{PhD}$ dissertation in geology, Universität Wien, Austria, $165 \mathrm{p}$.

Acharya, K. K., Edwards, M. and Grasemann, B., 2007, Adeformation based criteria for identifying the MCT in the north western part of the Kathmandu Nappe, central Nepal. Geophysical Research Abstracts, 9: 00729.

Dhital, M. R., Sunuwar, S. C., Shrestha R. and Tamrakar, N. K., 2000, Position of the MCT in Kathmandu-Melamchi area, central Nepal. Abs. Jour. Asian Earth Sci., v. 20(4a), pp. 9. 
Hagen, T., 1969, Report on the geological Survey of Nepal. Preliminary reconnaissance: Denkschriften der Schweizerischen Naturforchenden Gesellschaft, Memoires de la Societte Helvetique des Sciences naturees, Zurich, v. 86, 185 p.

Heim, A., and Gansser, A., 1939, Central Himalaya: Geological observations of the Swiss expedition 1936. Mem. Soc. Helv. Sci. Nat., v. 73(1), pp. 1-245.

Johnson, M. R. W., Oliver, G. J. G., Parrish, R. R., and Johnson, S. P., 2001, Synthrusting metamorphism, cooling, and erosion of the Himalayan Kathmandu complex, Nepal. Tectonics, v. 20, pp. 394-415.

Means, 1989, Stretching faults. Geology, v. 17, pp. 893-896.

Morrison, C. W. K. and Oliver, G. J. H., 1993, A study of illite crystallinity and fluid inclusions in the Kathmandu Klippe and the Main Central Thrust Zone, Nepal Himalayan Tectonics. Geol. Soc. Sp. Publ., no.74, pp. 525-540.

Nadgir, B. B., Gandotra, V. M., Nanda, M. M., Pawde, M. B., Sharma, P. N., 1968-1973, Nepal mission field reports. Geological Survey of India (Unpublished), Calcutta and Kathmandu.

Pearson, O. N. and DeCelles, G., 2005, Structural geology and regional tectonic significance of the Ramgarh thrust, Himalayan fold-thrust belt of Nepal. Tectonics, 24, TC4008, doi:10.1029/2003TC001617.

Paudel, L. P., 2000, Geological and Petrological study of the central Nepal Himalaya with reference to Tectono-Thermal Evolution and Inverted Metamorphism in the Lesser Himalaya. PhD thesis, Department of Earth and Planetary Sciences, Graduate School of science, Hokkaido University, Japan, 154 p..

Rai, S. M., Le Fort, P. and Upreti, B. N., 1997, Geology, structure and metamorphism in Kathmandu-Gosaikund regions, central Nepal. Abs. Jour. Nepal Geol. Soc. (Sp. Publ.), v. 16, pp. 20.
Rai, S. M., Gulliot, S., Le Fort, P. and Upreti, B. N., 1998, PressureTemperature Evolution in the Kathmandu and Gosaikunda region, Central Nepal. Jour. Asian Earth Sci., v. 16, pp. 283298.

Rai, S. M., 2001, Geology, geochronology and radiochronology of the Kathmandu and Gosainkund Crystalline nappes, Central Nepal Himalaya. Jour. Nepal Geol. Soc., v. 25 (Sp. Issue), pp. 135-155.

Robinson, D. M., DeCelles, P. G., Garzione, C. N., Pearson, O. N., Harrison, T. M., and Catlos, E. J., 2003, Kinematic model for the Main Central Thrust in Nepal. Geology, v. 31, pp. 359 -362 .

Sharma, C. K., 1973, Geology of Nepal. Mani Ram Sharma, Kathmandu, 189 p.

Sharma, C. K., 1977, Geology of Nepal. Educational Enterprises, Kathmandu, $164 \mathrm{p}$.

Stöcklin, J., Bhandari, A. N. and Bhattarai, K. D., 1976, Photogeological map of toposheet no-72A/14 west Chisapani south Dhading area. Report of Department of Mines and Geology/UNDP (unpublished).

Stöcklin, J., and Bhattarai, K. D., 1977, Geology of the Kathmandu area and central Mahabharat range, Nepal Himalaya. Report of Department of Mines and Geology/UNDP (unpublished), $86 \mathrm{p}$.

Stöcklin, J., 1980, Geology of Nepal and its regional frame. Jour. Geol. Soc. London, v. 137, pp. 1-34.

Upreti, B. N. and Le Fort, P. 1999, Lesser Himalayan crystalline nappe of Nepal: Problems of their origin. Geol. Soc. America (Sp. Paper), v. 328, pp. 225-238.

Yamaguchi, H., Arita, K., Takasu, A., 2004, Pressure-TemperatureDeformation paths of garnets from the Main Central Thrust zone surrounding the Kathmandu Nappe, Central Nepal Himalaya. Frontier Research on Earth Evolution, v. 2, pp. 8. 